\title{
IMPLEMENTASI PENDIDIKAN KARAKTER \\ PADA MADRASAH ALIYAH PUTERI AISYIAH \\ DI PALU
}

\section{The Implementation of Character Education in Madrasah Aisyiah Puteri in Palu}

\author{
Mujizatullah \\ Balai Penelitian dan Pengembangan Agama Makassar \\ Jl. A.P. Pettarani No.72 Makassar \\ Email: mujizatullahlitbang@gmail.com
}

Naskah diterima tanggal 26 Februari 2014. Naskah direvisi tanggal 22 Maret 2014. Naskah disetujui tanggal 3 April 2014

\begin{abstract}
Abstrak
Penelitian ini bertujuan untuk menggambarkan implementasi pendidikan karakter secara monolitik atau di integrasikan pada setiap mata pelajaran, faktor pendukung dan penghambat pelaksanaan pembelajaran tersebut. Studi ini dilakukan di Madrasah Aliyah putri Aisyiah dengan menggunakan pendekatan kualitatif. Hasil penelitian ini menyimpulkan bahwa implementasi pendidikan karakter dilaksanakan secara monolitik terlihat pada pelajaran aqidah akhlak, pengintegrasian pendidikan karakter terlihat pada proses pembelajaran pendahuluan, inti, dan penutup. Pembiasaan, pengembangan diri, karakteristik madrasah melalui pencitraan, dan komponen pendidikan, metode serta pendekatan yang digunakan dipadukan dengan metode berbasis pesantren, siswa diasramakan, sekolah dan asrama gratis. Salah satu faktor penghambat: adalah masih terdapat guru mengajar tidak sesuai dengan kompetensi profesional, pihak madrasah dan pihak asrama belum sinergi dalam menentukan kegiatan ekstrakurikuler yang berhubungan dengan pendidikan karakter.
\end{abstract}

Kata kunci: implementasi, pendidikan karakter, madrasah aliyah

\begin{abstract}
This research aimed at describing the implementation of character education monolithically or integrally in every subject, the supporting and abstracting factors of educational implementation. This study was conducted in Madrasah Aliyah 'Aisyiah' using qualitative approach. The result of the research concludes that the implementation of character education is done monolithically in Aqidah Akhlak subject. The integration of character education can be seen in the process of learning introduction, the teaching and learning process, and closing. The accustomed process, self-development, school characteristic through image projection, and education component, the method and approach used are integrated with Islamic school based method, students are in dorm, school and free dorm. One of the abstracting factors is there are still teachers teaching without having good professional competence. The school and dormitory parties are not synergic in deciding extracurricular activity related to character education.
\end{abstract}

Keywords : implementation, character education, madrasah aliyah

\section{PENDAHULUAN}

$\mathrm{P}$ embangunan karakter yang merupakan upaya perwujudan amanat Pancasila dan Pembukaan UUD 1945 dilatarbelakangi oleh realita permasalahan kebangsaan yang berkembang saat ini, seperti bergesernya nilai etika dalam kehidupan bangsa dan bernegara, memudarnya kesadaran terhadap nilai-nilai budaya bangsa, ancaman disintegrasi bangsa dan lemahnya kemandirian bangsa (Nury, 2012:93). 
Pendidikan karakter merupakan sebuah istilah yang semakin mendapatkan pengakuan dari orang Indonesia saat ini, setelah dirasakannya berbagai ketimpangan dan berperilaku yang tidak berkarakter, antara lain misalnya terjadi konflik dalam masyarakat, tawuran antar pelajar, antar etnik dan masalah sara (Sahlan, 2012:92). Krisis yang melanda pelajar mengindikasikan bahwa pendidikan agama dan moral yang didapat di bangku sekolah (kuliah) tidak berdampak terhadap perubahan perilaku manusia Indonesia (Gede, 2012: 64). Bahkan yang terlihat adalah begitu banyak yang tidak koheren antara ucapan dan tindakan. Kondisi demikian, diduga berawal dari apa yang dihasilkan oleh dunia pendidikan.

Penyerahan pendidikan karakter pada pendidik yang berada pada satuan pendidikan bukan jaminan akan berhasil dengan baik karena pendidik/guru hanya berada bersama mereka hanya dua jam pembelajaran ( $2 \times 45)$ menit seminggu, maka wajar kalau pendidikan karakter dewasa ini belum menunjukan hasil yang maksimal karena masih ada fenomena sosial yang menunjukan perilaku yang tidak berkarakter. Pembangunan karakter dilakukan dengan pendekatan sistematik dan integratif dengan melibatkan keluarga, satuan pendidikan, pemerintah, masyarakat sipil, anggota legislatif, media massa dan dunia usaha.

Oleh sebab itu, satuan pendidikan adalah salah satu komponen penting dalam pembangunan karakter secara sistemik dan integratif bersama dengan komponen pendidikan lainnya. Pencapaian hasil belajar siswa tidak dapat hanya dilihat dari ranah kognitif dan psikomotorik, sebagaimana selama ini terjadi dalam praktik pendidikan kita, tetapi harus juga dilihat dari hasil afektif, Ketiga ranah berhubungan secara resiprokal, meskipun kekuatan hubungannya bervariasi dari satu kasus ke kasus yang lain.

Penelitian tentang pendidikan karakter pernah dilakukan, antara lain oleh; (Gunawan, 2012:210), dengan judul pendidikan karakter konsep dan implementasinya, dan pendidikan karakter kajian teori dan praktek di sekolah. (Kesuma, dkk. 2012:180). Sehubungan dengan implementasi pendidikan karakter yang telah dipaparkan sebelumnya, maka pokok permasalahan dalam penelitian ini adalah implementasi pendidikan karakter pada satuan pendidikan. Dari masalah pokok tersebut diajukan masalah penelitian, yaitu bagaimana implementasi pendidikan karakter, bagaimana faktor penunjang dan faktor penghambat di dalam mengimplementasikan pendidikan karakter pada satuan pendidikan agama MA Puteri Aisyiah Palu.

Hasil penelitian ini diharapkan dapat memberikan konstribusi pemikiran kepada pihak terkait diantaranya Kementerian Agama untuk pemberdayaan guru mengenai pendidikan karakter secara monolitik dan mengintegrasikan pada semua mata pelajaran di MA Putri Aisyiah Palu melalui komponen pendidikan, yaitu pendidik, peserta didik, materi pembelajaran, metode, sistem evaluasi dan sarana parasarana.

Ruang lingkup penelitian ini meliputi implementasi pendidikan karakter, adalah preoses pendidikan karakter secara monolitik atau secara intigratif pada muatan pembelajaran dan dilihat melalui instrument/komponen pendidikan, yaitu pendidik, peserta didik, materi pembelajaran, metode, sarana parasarana dan sistem evaluasi. Satuan pendidikan, adalah satuan pendidikan agama, yaitu Madrasah Aliyah Putri Aisyiah yang terdapat di Palu Sulawesi Tengah.

\section{Tinjauan Pustaka}

Pendidikan karakter adalah pendidikan pembiasaan, praktik internalisasi dan transformasi nilai-nilai yang baik kedalam diri seseorang yang bukan hanya sekedar mengajarkan atau memberikan pengetahuan tentang baik dan buruk. Seakan-akan perilaku seperti itu menjadi tradisi yang menjurus pada tindak kekerasan yang meresahkan masyarakat, bahkan pada tindakan keriminal, seperti pemalakan, penganiayaan bahkan pembunuhan (Gunawan, 2012: 210).

Implementasi pendidikan karakter, adalah proses pendidikan karakter secara monolitik atau secara intigratif pada muatan pembelajaran dan dilihat melalui instrument/komponen pendidikan, yaitu pendidik, peserta didik, materi pembelajaran, metode, sarana parasarana dan sistem evaluasi.

Peserta didik dalam proses pendidikan manusia yang memerlukan bimbingan (Hasballah, 1999:73). Kurikulum harus didesain berdasarkan pada pemenuhan kebutuhan (Prawiroatmojo, 
1987:15). Dalam konteks kurikulum pendidikan Agama Islam, kurikulum idealnya tidak disusun secara sentralistik karena walaupun agama berlaku universal, tetapi problem kehidupan keagamaan menjadi lokal sektoral.

Metode pembelajaran merupakan suatu prosedur dalam mengajar (Rahim, 2001:20). Metode pendidikan berkarakter terdiri dari Metode hiwar atau percakapan, metode qishah atau cerita, metode Amtsal (perumpamaan). Metode Uswahatau keteladanan. Metode pembiasaan sesuatu yang sengaja dilakukan secara berulang-ulang agar menjadi kebiasaan.

Sarana dan prasarana adalah seluruh fasilitas yang digunakan dalam proses pembelajaran (Muslich, 2011:65). Sarana pendidikan adalah peralatan dan perlengkapan yang secara langsung dipergunakan untuk menunjang proses pendidikan, khususnya proses belajar mengajar, seperti gedung, ruang kelas, meja, kursi, serta alat-alat dan media pengajaran (Sungkowo, 2009:98). Adapun yang menjadi prasarana pendidikan, adalah fasilitas secara tidak langsung menunjang jalannnya proses pembelajaran, antara lain seperti halaman, kebun, taman sekolah, jalan menuju sekolah. (Fatchurochman, 2012:82).

Sistem evaluasi di dunia pendidikan dikenal dengan pengawasan dan supervisi. Hal ini mengacu kepada Permen Diknas nomor 19/2007, bahwa standar pengelolaan pendidikan tersurat istilah pengawasan dan evaluasi dan supervisi akademik, walaupun supervisi itu sendiri sekaligus merupakan bagian dari pengawasan (Sukmadinata dkk, 2008:52).

Landasan hukum pendidikan karakter, Undang-Undang Dasar Negara Republik Indonesia 1945, fasal 31 ayat (1) menyebutkan bahwa setiap warga negara berhak mendapat pendidikan. Ayat (3) menegaskan bahwa pemerintah mengusahakan dan menyelenggarakan suatu sistem pendidikan nasional yang meningkatkan keimanan dan ketakwaan serta akhlak mulia dalam rangka mencerdaskan kehidupan bangsa yang diatur dengan undangundang.untuk itu seluruh komponen bangsa wajib mencerdaskan kehidupan bangsa yang merupakan salah satu tujuan negara Republik Indonesia.

Rencana Pembangunan Jangka Panjang Nasional (RPJMN) tahun 2005-2015 di mana pendidikan karakter ditempatkan sebagai landasan untuk mewujudkan visi pembangunan nasional, yaitu mewujudkan masyarakat yang berakhlak mulia, bermoral, beretika, berbudaya dan beradab berdasarkan falsafah Pancasila.

Undang-Undang Sistem Pendidikan Nasional Nomor 20 tahun 2003 Bab II Pasal 3 bahwa pendidikan nasional berfungsi mengembangkan kemampuan dan membentuk watak serta peradaban bangsa yang bermartabat dalam rangka mencerdaskan kehidupan bangsa, yang bertujuan untuk berkembangnya potensi peserta didik agar menjadi manusia yang beriman dan bertakwa kepada Tuhan Yang Maha Esa, berakhlak mulia, sehat, berilmu, cakap, kreatif, mandiri, dan menjadi warga negara yang demokratis serta bertanggung jawab.

Peraturan Pemerintah Nomor 55 tahun 2007 tentang pendidikan agama, pasal 5 ayat (3) pendidikan agama mendorog peserta didik untuk taat menjalankan ajaran agamanya dalam kehidupan sehari-hari dan menjadikan agama sebagai landasan etika dan moral dalam kehidupan pribadi, keluarga, masyarakat, bangsa dan bernegara.

Peraturan Menteri Pendidikan Nasional Nomor 23 tahun 2006 tentang Standar Kompetensi Lulusan (SKL) untuk satuan pendidikan dasar dan menegah. peraturan Menteri Pendidikan Nasional Nomor 22 Tahun 2006 tentang Standar Isi (SI) untuk satuan pendidikan dasar dan menengah, terutama pada mata pelajaran Pendidikan Agama Islam (PAI) aspek keimanan/aqidah dan akhlak untuk SMA/ MA.

Surat Edaran Dirjen Pendidikan Islam Nomor: DJ.II.1/PP.00/ED/681/2006, tanggal 1 Agustus 2006, tentang pelaksanaan Standar Isi, yang intinya bahwa madrasah dapat meningkatkan kompetensi lulusan dan mengembangkan kurikulum dengan standar yang lebih tinggi.

Pendidikan karakter telah menjadi perhatian berbagai negara dalam rangka mempersiapkan generasi yang berkualitas, bukan hanya untuk kepentingan individu warga negara, tetapi juga untuk warga masyarakat secara keseluruhan. Pendidikan karakter dapat diartikan sebagai usaha kita secara sengaja dari seluruh dimensi kehidupan madrasah untuk membantu pembentukan karakter secara optimal (Abdullah, 2005:86). 
Berdasarkan tujuan pendidikan nasional, maka pendidikan karakter adalah suatu program pendidikan sekolah dan luar sekolah yang mengorganisasikan dan menyederhanakan sumbersumber moral dan disajikan dengan memperhatikan pertimbangan psikologis untuk pertimbangan pendidikan.

\section{METODE PENELITIAN}

Penelitian ini dilakukan di Kota Palu Provinsi Sulawesi Tengah, dengan sasaran lokasi penelitian adalah Madrasah Aliyah Puteri Aisyiah Kota Palu. Menggunakan pendekatan kualitatif, peneliti menjadi bagian dari key instrument (Bogdan, 1982:27). Peneliti mencoba memperoleh gambaran tentang implementasi pendidikan karakter di Madrasah Aliyah Puteri Aisyiah Kota Palu, secara monolitik dan integratif, dan faktor pendukung dan penghambat implementasi pendidikan karakter di Madrasah Aliyah Puteri Aisyiah Kota Palu. Jenis data, adalah data sekunder dan data primer.Data primer yang berhubungan langsung dengan objek penelitian yaitu guru mata pelajaran, kepala MA Puteri Aisyiah Kota Palu, pembimbing asrama komite sekolah pengawas orang tua siswa Kabid Mapenda Kota Palu, data sekunder dokumen pendukung misalnya profil sekolah dokumen kurikulum, silabus dan RPP Madrasah Aliyah Puteri Aisyiah Kota Palu.

Langkah-langkah yang digunakan dalam analisis ini adalah reduksi data, dan verifikasi data (Sugiono, 2005:2). Kegiatan analisis dapat dilakukan sejak pengumpulan data sampai penulisan hasil laporan penelitian.

\section{PEMBAHASAN}

\section{Profil MA Putri Aisyiah Palu}

Madrasah Aliyah putri Aisiyah terletak di Jl. Hang Tuah no 104 Kelurahan Talise Kecamatan Mantikulore Kota Palu, struktur organisasi terdiri dari kepala madrasah, wakil kepala madrasah, dan tata usaha, kepegawaian, kesiswaan, kurikulum, perlengkapan, keuangan, pustaka, kesra, dan siswa. Madrasah ini berada pada kelompok kerja Madrasah Aliyah Negeri Model Palu. Dasar pendirian: AlQuran Surat Ali Imron ayat 104 dan Surat Abasa ayat 1-4. Visi madrasah: Terciptanya kreativitas siswa serta kinerja sekolah yang berwawasan
Imtaq dan Iptek. Misi, melaksanakan proses pembelajaran yang aktif, efektif, dan inovatif dalam mengembangkan potensi intelektual keterampilan siswi, meningkatkan kesadaran dan semangat siswi sehingga mampu menjadi manusia yang beriman dan bertakwa sebagai landasan berpikir, bersikap dan bertingkah laku dalam kehidupan seharihari dan menciptakan pemimpin masa depan yang berwawasan Islam. Motto: Menciptakan dan menghasilkan siswi madrasah yang penuh dengan etika, sopan santun serta bernuansa intelektual Islam.

\section{Keadaan Pendidik MA Puteri Aisyiah Palu}

Keadaan pendidik MA puteriAisyiahPalu 2012-2013. Jumlah pendidik di MA putri Aisyiah Palu, pendidik PNS diperbantukan tetap 4 orang, guru tetap yayasan 3 orang, pendidik honorer 8 orang, pendidik tidak tetap 6 orang, dan mempunyai latar belakang pendidikan minimal $\mathrm{S} 1$ dan dua orang S2 dengan jurusan yang variatif: jurusan tarbiyah, syariah, pertanian, peternakan, sospol, FKIP kimia, FKIP Untad. Guru bimbingan konseling yang dilaksanakan diasrama pada sore hari bagi anak yang bermasalah misalnya siswa yang malas shalat, sering keluar tanpa izin dan sebagainya.

Pendidik mempunyai tugas utama mendidik, mengajar, membimbing, mengarahkan, melatih, menilai, dan mengevaluasi pada peserta didik. Peran guru yang memfasilitasi diinternalisasinya nilai-nilai kepada siswa antara lain guru sebagai fasiliator, motivator, partisipan, dan pemberi umpan balik. Pendidik yang dengan efektif dan efisien mengembangkan karakter siswa adalah mereka yang di depan guru berperan sebagai teladan/memberi contoh, di tengah-tengah peserta didik guru membangun prakarsa dan bekerja sama dengan mereka, di belakang guru memberi daya semangat dan dorongan bagi peserta didik.

\section{Keadaan Peserta Didik MA Puteri Aisyiah Palu}

Siswa MA putri Aisyiah 2012-2013 terdiri dari kelas X 22, kelas XI 17, kelas XII 12, jumlah keseluruhan 51, peserta didik semua tinggal di asrama, asal siswa selain dari Kota Palu juga terdapat dari berbagai daerah seperti Parigi Mutong, Donggala, Luwu, Toli-toli, Banggai, Towuna, dan Ampana. Peserta didik harus diberi 
peran aktif dalam pembelajaran antara lain sebagai partisipan diskusi, pelaku eksperimen, penyaji hasil-hasil diskusi dan eksperimen agar peserta didik mempraktekkan nilai-nilai karakter yang ditargetkan danperlu diaplikasikan pada semua tahapan pembelajaran, karena prinsip-prinsip pembelajaran tersebut sekaligus dapat memfasilitasi terinternalisasinya nilai-nilai.

Selain itu, perilaku guru sepanjang proses pembelajaran harus merupakan model pelaksanaan nilai-nilai bagi peserta didikasalnya bukan hanya dari kota Palu juga terdapat dari berbagai daerah seperti Parigi Mutong, Donggala, Luwu, Toli-toli, Banggai, Towuna, dan Ampana. Siswa semua tinggal di asrama. Nilai-nilai utama yang dikelompokkan menjadi nilai-nilai yang berhubungan dengan ketuhanan, diri sendiri, sesama manusia, lingkungan dan kebangsaan yang merupakan fokus dari pendidikan karakter.

Pendidikan karakter di sekolah terdiri dari beberapa kegiatan pembinaan kesiswaan dalam rangka implementasi pendidikan karakter di Madrasah. Kegiatan pembinaan itu mencakup masa orientasi peserta didik atau masa orientasi siswa pembinaan keimanan dan ketakwaan kepada Tuhan Yang Maha Esa, Organisai Siswa Intra Sekolah, kepramukaan, penegakan disiplin dan tata tertib sekolah, upacara bendera, pendidikan pencegahan penyalahgunaan narkoba dan pembinaan bakat dan minat. Olimpiade sains dan ekonomi, dilaksanakan oleh Kementerian Agama kota dan provinsi mendapat juara satu untuk tingkat Kota Palu dan juara tiga untuk tingkat Provinsi Sulawesi Tengah yang dilaksanakan pada tanggal 16 Juni 2013. Selanjutnya olimpiade sains Bahasa Inggris yang dilaksanakan di Universitas Gajamada pada tanggal 31 Maret 2013 dengan mendapat sertifikat nilai A dan B. Kepramukaan merupakan proses pendidikan di luar lingkungan sekolah dan di luar lingkungan keluarga dalam bentuk kegiatan menarik, menyenangkan, sehat, teratur, terarah, praktis yang dilakukan di alam terbuka yang sasaran akhirnya adalah untuk pembentukan watak, akhlak dan budi pekerti luhur.

\section{Kurikulum}

Struktur kurikulum pendidikan nasional terdapat dua mata pelajaran yang terkait langsung dengan pengembangan budi pekerti dan akhlak mulia yaitu pendidikan Agama dan PKn. Kedua mata pelajaran tersebut merupakan mata pelajaran yang secara langsung eksplisit mengenalkan nilainilai ndan sampai taraf tertentu menjadikan peserta didik peduli dan menginternalisasi nilai-nilai.

Prinsip-prinsip pengembangan Rancangan PElaksanaan Pembelajaran berkarakter sebagai berikut kompetensi yang dirumuskan dalam RPP harus jelas, agar semakin mudah diamati dan akan semakin tepat kegiatan yang harus dilakukan untuk membentuk kompetensi tersebut. RPP yang dibuat di MA Puteri Aisyiah Palu sederhana dan fleksibel serta dapat dilaksanakan dalam kegiatan pembelajaran dan pembentukan kompetensi peserta didik; Kegiatan pembelajaran yang dikembangkan dalam RPP menunjang dan sesuai dengan kompetensi dasar yang akan diwujudkan di madrasah tersebut. RPP yang dikembangkan utuh dan menyeluruh serta jelas pencapaiannya ada koordinasi antar komponen pelaksanaan program di madrasah, terutama apabila pembelajaran ekstrakurikuler dilakukan di sore hari atau dilaksanakan di luar kelas, agar tidak mengganggu jam-jam belajar yang lain.

Pendidikan karakter terlihat sebelum dimulai pelajaran siswa dan guru berbaris di lapangan. Setelah itu, siswa bersalaman dengan cium tangan kepada guru begitu pula guru salaman dengan sesama guru dan kepala sekolah. Selanjutnya siswa masuk di kelas satu persatu dan salaman lagi dengan guru dan mencium tangan guru. Selanjutnya, dimulai kegiatan pendahuluan pembelajaran dengan membaca doa dan tadarus selama 15 menit. Selain pembiasaan tersebut terlihat di halaman madrasah dan disetiap sudut ruangan dan di depan ruangan terdapat tanaman hias. Oleh karena itu, madrasah tersebut terlihat menghijau dengan tanaman hias dan tanaman toga (tanaman obat keluarga).

Pelaksanaan pendidikan karakter secara monolitik di MA Puteri Aisyiah Palu mengacu kepada silabus dan RPP yang dibuat/disiapkan sebelumnya adalah pelajaran agama: Aqidah Akhlaq, kurikulumnya terdiri dari Standar Kompetensi dan Kompetensi Dasar dan pelajaran yang diintegrasikan pada semua bidang studi. Yang mengacu pada 18 nilai yang bersumber dari agama, budaya yang ingin dicapai dalam pendidikan 
karakter sesuai dengan tujuan pendidikan nasionsl diantara ke 18 nilai tersebut.

Nilai yang paling dominan yang diintegrasikan pada setiap mata pelajaran adalah nilai etika, kejujuran, toleransi, disiplin, menghormati yang lebih tua, persoalan akhlakul karimah. Selain hal tersebut, pelajaran pengembangan diri, misalnya latihan perawatan jenazah, ceramah (kultum) tiap hari setelah shalat dzuhur. Selanjutnya, setiap hari sabtu setelah dzuhur sekitar jam 2 terdapat pembiasaan memperhatikan kebersihan lingkungan. Selain hal tersebut, guru akhlak menanamkan akhlakul karimah sebelum digaungkan pendidikan karakter. Ektrakurikuler peningkatan pengetahuan siswa persiapan mengikuti ilmu pengetahuan seni budaya (kaligrafi) peningkatan pengetahuan sains, pengembangan diri, pendidikan dan pembinaan guru menyampaikan kultum, khotbah dan lain sebagainya. Perawatan jenazah, pengembangan usaha pertanian mandiri, muatan lokal: bahas Arab, kemuhammadiyaan, keterampilan wanita, dan kearifan lokal Palu diantaranya Nosarara Nosabatutu, (kita hidup bersama-sama secara aman dan damai bersatu) yang merupakan pelajaran bagi siswa karena guru selalu menanamkan kebersamaan antara siswa dan guru, karena siswa asalnya berbedabeda.

\section{Langkah-langkah Kegiatan Pembelajaran}

Kegiatan pembelajaran madrasah terdiri atas kegiatan pendahuluan. Sebelum kegiatan pembelajaran terlebih dahulu guru memberi salam, kemudian dimulai dengan pembacaan doa. Proses ini berlangsung selama 15 menit, apresepsi dan motivasi: memberikan salam pembuka, menanyakan kepada siswa tentang pengertian dan pentingnya husnudz-dzan dan bertaubat. Kegiatan Inti (pembelajaran) tanya jawab awal tentang pengertian dan pentingnya husnudz-dzan dan bertaubat. Pendidik memberikan ilustrasi tentang pengertian dan pentingnya husnudz-dzan dan bertaubat. menyebutkan tentang pengertian dan pentingnya husnudz-dzan dan bertaubat. Mendiskusikan dalam kelompok tentang pengertian dan pentingnya husnudz-dzan dan bertaubat. Siswa mempresentasi hasil diskusi kelompok tentang pengertian dan pentingnya husnudz-dzan dan bertaubat. Kegiatan penutup, pendidik mengulang kembali seluruh materi yang telah disampaikan, dan menyuruh siswa untuk mengingat sebagai tugas rumah dan akan dipraktekkan pada pembelajaran agama berikutnya. Setiap siswa diwajibkan mempresentasikan masalah khusnudzdzan dan bertaubat. Mendiskusikan masalah perbedaan antara husnudz-dzan dan bertaubat. Setiap selesai pembelajaran guru melakukan doa penutup mengakhiri kegiatan pembelajaran dengan mengucapkan salam penutup dan mengajak siswa untuk tetap didalam kelas untuk menerima materi berikutnya dari guru yang lain.

Pengintegrasian pendidikan karakter pada salah satu mata pelajaran Teknologi Informasi dan Komunikasi kelas X semester 2 standar kompetensi menggunakan operating system komputer, waktu 2x45 menit, kompetensi dasar melakukan operasi dasar pada operating system computer. Tujuan pembelajaran: setelah proses belajar mengajar siswa diharapkan dapat mengoptimalkan komputer. Karakter siswa yang diharapkan, disiplin, kerja keras, kreatif, rasa ingin tahu, cinta tanah air, menghargai prestasi, bersahabat, cinta damai, gemar membaca, tanggung jawab. Kewirausahaan/ekonomi kreatif: percaya diri, berorientasi tugas dan hasil, berani mengambil resiko, berorientasi ke masa depan.

Langkah-langkah kegiatan pembelajaran, pendahuluan, menyampaikan kompetensi dasar dan indikator pencapaian kompetensi pembelajaran, apersepsi tentang cara orang berbicara dari dua bangsa yang memiliki bahasa beerbeda, motivasi cara penerjemahan dari bahasa mesin ke bahasa manusia atau sebaliknya. Kegiatan inti dalam eksplorasi, pendidik menginformasikan prosedur awal menghidupkan dan mematikan komputer dengan benar, pendidik menginformasikan akibat dari menghidupkan atau mematikan yang tidak benar, menginformasikan fungsi dari operating system sebagai pengatur disk drive, hardisk, cd/ dvd, keyboard, monitor, mouse, printer, dan sebagainya. Konfirmasi, dalam kegiatan konfirmasi siswa menyimpulkan tentang hal-hal yang belum diketahui nilai yang ditanamkan disiplin, kerja keras, kreatif, rasa ingin tahu, cinta tanah air, menjelaskan tentang hal-hal yang belum diketahui. Nilai yang ditanamkan menghargai prestasi, bersahabat, cinta damai, gemar membaca, dan tanggung jawab. Kegiatan penutup dimaksudkan untuk mengevaluasi 
dengan memberikan pertanyaan seputar indikator yang ingin dicapai.

Nilai yang ditanamkan, disiplin, kerja keras, kreatif, rasa ingin tahu, cinta tanah air, menghargai prestasi, bersahabat, cinta damai, gemar membaca, tanggung jawab, Siswa disuruh untuk membuatkan rangkuman dari pembelajaran pada hari ini.

\section{Sarana dan Prasarana}

Pendidikan merupakan kegiatan yang bertujuan untuk memperoleh sarana pendidikan yang diperlukan guna kelancaran proses pendidikan dan pengajaran, Prasarana pendidikan adalah semua benda atau fasilitas yang mempermudah dan memperlacar proses pendidikan dan pengajaran, tetapi sifatnya tidak langsung, misalnya ruang kelas/ gedung, meja kursi, yang ada di lembaga pendidikan. Sarana pendidikan adalah semua fasilitas yang mempermudah dan memperlancar proses pendidikan dan pengajaran dan sifatnya langsung, misalnya papan tulis, buku, dan sebagainya.

Secara garis besar fasilitas atau sarana dapat dibedakan menjadi fasilitas fisik dan fasilitas uang/ non fisik. Fasilitas fisik adalah segala sesuatu yang berupa benda atau yang dapat dibedakan, yang mempunyai peranan dalam memudahkan dan mempelancar suatu kegiatan. Fasilitas fisik juga sering disebut fasilitas materil. Fasilitas pendidikan yang termasuk fasilitas fisik antara lain ruang kelas, perabot ruang kelas, dan perabot ruang perpustakaan.

Fasilitas non fisik adalah segala sesuatu yang bersifat mempermudah dan memperlancar kegiatan sebagai akibat berkerjanya nilai-nilai non fisik misalnya uang, waktu, kepercayaan dan sebagainya.

Ketersediaan sarana dan prasarana yang ada di Madrasah Aliyah Aisyiah Palu, sekolah ini memiliki fasilitas yang lengkap baik dari aspek sarana kegiatan pembelajaran maupun sarana pendukung lainnya diantaranya: ruang kelas, aula, perpustakaan, laboratorium IPA, biologi, fisika, ruang laboratorium kimia, komputer, bahasa, dan ruangan pimpinan, guru, tata usaha, konseling, tempat beribadah, UKS, jamban, gudang, sirkulasi, tempat olahraga, organisasi kesiswaan. Mobiler terdiri dari: kursi kepala madrasah, meja kepala madrasah, kursi wakil kepala madrasah, meja wakil kepala madrasah, kursi guru, meja guru, kursi tata usaha, meja tata usaha, kursi siwa, meja siswa, lemari, komputer, papan tulis, peralatan menjahit dan alat musik.

\section{Metode Implementasi Pendidikan Karakter}

Metode Pembelajaran yang digunakan di MA Putri Aisyiah menggunsatunakan metode ceramah, demonstrasi, tanya jawab, diskusi kelompok, inkuiri, dan pengamatan.

Pendekatan yang digunakan dalam pembelajaran implementasi pendidikan karakter pada pelajaran umum adalah dengan mengintegrasikan pendidikan karakter pada mata pelajaran tersebut. Salah satunya strategi dalam mengimplementasikan pendidikan karakter pada mata pelajaran TIK. Pendidik menginformasikan prosedur awal menghidupkan dan mematikan komputer dengan benar. Dan untuk mata pelajaran akidah akhlak implementasi pendidikan karakter pada mata pelajaran ini dilaksanakan secara monolotik .

Dihubungkan dengan pendidikan karakter misalnya disiplin hadir tepat waktu, kerja keras siswa mengerjakan tugas harian dan rumah. Semangat kebangsaan, cinta tanah air, rasa ingin tahu saat praktek TIK anak bertanya pada guru tentang langkah kerja. Semangat kebangsaan terlihat saat siswa ingin mengikuti lomba IPTEK di ajang internasional. cinta tanah air saat siswa ingin menciptakan suatu tekhnologi baru. Menghargai prestasi terlihat saat siswa senang dengan nilai semester yang diperoleh. Komunikatif terlihat saat anak praktek dalam satu kelompok. Mereka bekerja sama dan saling mengajarkan pada teman yang belum paham. Cinta damai terlihat saat anak mendamaikan teman yang saling berselisih paham. Gemar membaca terlihat saat anak sering mengunjungi perpustakaan bila guru berhalangan hadir. Peduli lingkungan terlihat saat anak membersihkan kelas dan halaman sekolah sesuai dengan pembagian tugas masing-masing. Peduli sosial terlihat saat anak bersatu padu foto copy materi pelajaran untuk keperluan bersama dengan mengumpulkan uang biaya foto copy secar suka rela. Setiap habis praktek TIK, siswi selalu diajarkan untuk selalu bersyukur dengan menggunakan tekhnologi kearah positif, jangan digunakan kearah negatif misalnya belajar internet. 
Implementasi pendidikan karakter dilaksanakan secara monolotik yakni Aqidah Akhlak dan di Integrasikan pada semua mata pelajaran diantaranya pelajaran muatan lokal pertanian, pendidikan karakter diintegrasikan pada pelajaran tersebut dari sisi mencintai lingkungan hidup yaitu pertanian, pengembangan tanaman, pengembangan pasca panen. Misalnya: ubi dapat dikelola menjadi keripik. Out put dari pelajaran tersebut siswa diharapkan dapat mandiri dan kreatif dan peduli lingkungan, peduli terhadap masyarakat. dengan memberikan contoh pada masyarakat agar memanfaatkan tanaman yang ada di lingkungannya. Kaitannya dengan pendidikan karakter siswa diharapkan mempunyai budi pekerti yang baik. Apalagi di madrasah tersebut semuanya adalah wanita. Kemudian mengenal dan mencintai tanaman. Misalnya: siswa mengumpulkan tanaman khias dan mengembangkannya melalui pembibitan pemeliharaan tanaman yang bermanfaat bagi keluarga dan mencoba mengenalkan bumbu-bumbu dapur seperti kunyit, lada, dan lain sebagainya agar anak dapat mandiri.

Kegiatan proses pembelajaran di MA Aisyiah sangat erat kaitannya dengan kegiatan di asrama. Misalnya kegiatan sehari-hari: kegiatan ekstrakuler yang pelajari di sekolah dikembangkan di asrama kegatan ekstrakuler diantaranya POKJA terdiri dari pokja membersihkan kamar mandi, memasak, cuci piring membersihkan halaman belakang, membersihkan mesjid, memersihkan halaman depan, membesihkan aula. Jumlah anak panti 55 orang yang terdiri perempuan berasal dari hampir semua kabupaten yang merupakan binaan dari Aisyiah. Kegiatan habis shalat asar tausiah, membimbing siswa yang kurang benar yang dimbing oleh ibu hayati setelah shalat magrib menghafal Alquran, juz ammah, surat-surat yang pajang. Metode yang digunakan sistem pengajian. Pembimbingan mengajar mengaji oleh kakak kelas dan ketika waktu isya semua kegiatan di hentikan untuk mendengarkan adzan.

Pendidikan karakter diintegrasikan pada semua kegiatan yang dilaksanakan pada sore hari dari jam 16.00. Kegiatan harian panti putri Aisyiah berbasis pesantren dibina oleh ibu hayati dan Ibu Asma. Kegiatannya sebagai pengembangan pelajaran di pagi hari dikembangkan pada sore hari mulai dari jam: 16.00-18.00. Shalat tahajud, sholat subuh berjamaah, dan tausiyah, jam 06.00-07.00: persiapan pribadi, Pokja (kelompok kerja), dan makan pagi jam 07.00-15.30: kegiatan sekolah formal, sholat dzuhur berjamaah, dan makan siang jam 15.30-17.00: sholat ashar berjamaah, kuliah ashar jam 17.00-18.00: kegiatan pribadi, Pokja jam 18.00-19.30: sholat magrib berjamaah, tahsin dan tajwid/takhfid/tafsir isya berjamaah jam 19.30-20.00: makan malam jam 20.00- 22.00: belajar mandiri. Pendidikan karakter diintegrasikan pada semua kegiatan tersebut di atas terutama pada kegiatan kultum setelah shalat magrib dan tausiyah materinya dilebih banyak kepada materi akhlakul karimah, hadis ibadah berdasarkan acuan keputusan majelis tarjih.

Terlihat pendidikan karakter melalui pembiasaan dan keteladanan pada karakteristik madrasah melalui pencitraan diantaranya ketika memasuki pintu gerbang sekolah terlihat dihampir setiap dinding sekolah tertulis pesan dan kesan pendidikan karakter yang termuat dalam 18 butir diantaranya $8 \mathrm{~K}$ : ketakwaan, keindahan, kebersihan, kesehatan, keamanan, ketertiban, kekekluargaan, dan keindahan. Kemudian pada setiap pintu masuk tertuliskan pesan dengan kata "Saya malu datang terlambat dan saya malu jika cepat pulang. Pada waktu shalat tiba, seluruh kegiatan dihentikan". Selanjutnya, di dinding pintu masuk ruang guru tertulis "kebersihan sebagian dari iman, malu sebagian dari Ima dan tertera tata tertib madrasah dipintu masuk ruang guru dan ruang kepala sekolah dilengkapi dengan pembagian tugas guru dan kepala sekolah serta jajarannya, shalat dhuha yang dilaksanakan pada jam istirahat pertama pada jam sembilan selama lima belas menit dan puasa senin kamis dengan salah satu cara menutup dapur pada hari tersebut bekerja sama dengan asrama dan bagi yang berhalangan tetap diberi bahan makanan untuk dimasak sendiri.

\section{Implementasi Pendidikan Karakter di MA Putri Aisyiah Palu}

Pengimpelementasian pendidikan karakter terlihat pada budaya Madrasah salah satunya terdapat pada pembiasaan dan keteladanan, diantaranya guru langsung memberikan contoh dalam kelas untuk memberikan salam dan guru terlebih dahulu 
menyapa kepada siswa dan memberikan contoh tentang kejujuran dan pembiasaan tersebut terlihat pada setiap dinding kelas dan pintu masuk itu terdapat butir-butir pendidikan karakter sebanyak 18 butir misalnya: salah satu pintu masuk terdapat kata $7 \mathrm{~K}$ : ketakwaan, keimanan dan seterusnya, di depan pintu kelas terdapat pesan tanggung jawab, saya malu apabila saya terlambat, dan saya malu apabila saya cepat pulang, waktu sholat semua kegiatan dihentikan. Sosialisasi pengenalan di antaranya, sholat, bukan hanya shalat dhuhur di sekolah saja, tetapi shalat di luar sekolah sebanyak lima waktu tetap harus dilakukan berjamaah, karena didukung oleh pembina di panti berbasis pesantren tersebut, pelestarina lingkungan hidup, tanaman bunga, apotik hidup semuanya terlihat pada halaman sekolah dan di sudut-sudut pintu ruangan MA Aisyah putri Palu.

Pendidikan karkter dilaksanakan dengan cara diintegrasikan pada semua mata pelajaran kecuali pelajaran aqidah akhlak sudah dilaksanakan secara monolitik karena sudah mempunyai RPP dan silabus tersendiri. Selanjutnya, didinding pintu masuk ruang guru tertulis "kebersihan sebagian dari iman, malu sebagian dari iman" dan tertera tata tertib madrasah dipintu masuk ruang guru dan ruang kepala sekolah dilengkapi dengan pembagian tugas guru dan kepala sekolah serta jajarannya. Pembiasaan dan keteladanan terlihat pada siswa shalat duha yang dilaksanakan setiap hari pada jam istirahat selama lima belas menit, puasa senin dan kamis kerja sama madrasah dan asrama dengan cara dapur ditutup dan bagi anak yang berhalangan diberikan kesempatan untuk memasak sendiri.

Setiap mata pelajaran memfokuskan pada penanaman nilai-nilai utama tertentu yang paling dekat dengan karakteristik mata pelajaran yang bersangkutan. Selanjutnya, didinding pintu masuk ruang guru tertulis "kebersihan sebagian dari iman, malu sebagian dari iman" dan tertera tata tertib madrasah dipintu masuk ruang guru dan ruang kepala sekolah dilengkapi dengan pembagian tugas guru dan kepala sekolah serta jajarannya. Pembiasaan dan keteladanan terlihat pada siswa shalat dhuha yang dilaksanakan setiap hari pada jam istirahat selama lima belas menit antara jam sembilan dan sepuluh, puasa senin dan kamis kerja sama madrasah dan asrama dengan cara dapur ditutup dan bagi anak yang berhalangan diberikan kesempatan untuk memasak sendiri.

Setiap mata pelajaran memfokuskan pada penanaman nilai-nilai utama tertentu yang paling dekat dengan karakteristik mata pelajaran yang bersangkutan. Pendidikan Agama Islam nilai-nilai yang ditanamkan: religius, jujur, santun, disiplin, bertanggung jawab, cinta ilmu, ingin tahu, percaya diri, menghargai keberagaman, dan patuh pada aturan sosial.

PKn: nasionalis, patuh pada aturan sosial, demokratis, jujur, menghargai keberagaman, dan sadar akan hak. Mata pelajaran bahasa Indonesia: berfikir logis, kritis, kreatif dan inovatif, percaya diri, bertanggung jawab, ingin tabu, santun. Matematika: berpikir logis, kritis, jujur, kerja keras, dan ingin tahu.

Mata pelajaran Sosial atau IPS: nasionalis, menghargai keberagaman, berpikirlogis, kritis, kreatif, dan inovatif, dan peduli sosial. Ilmu Pengetahuan Alam: ingin tatu, berpikir logis, kritis, kreatif, dan inovatif, jujur, bergaya hidup sehat, percaya diri, monghargai keberagaman, disiplin, mandiri, bertanggung jawab, peduli lingkungan, cinta ilmu. Bahasa Inggris: Menghargai keberagaman, santun, percaya diri, mandiri, bekerjasama, patuh pada aturan sosial.

Mata pelajaran Seni Budaya: Menghargai keberagaman, nasionalis, dan menghargai karya orang lain, ingin tahu, jujur, disiplin, demokratis. Penjaskes: Bergaya hidup sehat, kerja keras, disiplin, jujur, percaya diri, mandiri, menghargai karya danprestasi orang lain. TIK/keterampilanberpikir logis, kritis, kreatif, dan inovatif, mandiri, bertanggung jawab, dan menghargai karya orang lain. Muatan Lokal menghargai keberagaman, menghargai karya orang lain, nasionalis, dan peduli.

\section{Evaluasi Implementasi Pendidikan Karakter}

Pada tahap evaluasi hasil, dilakukan penilaian program untuk perbaikan berkelanjutan yang dirancang dan dilaksanakan ntuk mendeteksi aktualisasi karakter dalam diri peserta didik sebagai indikator bahwa proses pembudayaan dan pemberdayaan karakter itu berhasil dengan baik, menghasilkan sikap yang kuat, dan pikiran yang argumentatif. 
Bentuk evaluasi yaitu formatif maupun sumatif.Kedua jenis evaluasi ini dimaksudkan untuk mengetahui keberhasilan guru dalam mengajar dilihat dari prestasi atau hasil yang telah dikuasai siswa, yang pada akhirnya diarahkan untuk mengkaji seberapa jauh kurikulum telah dilaksanakan.

Evaluasi formatif adalah evaluasi atau penilikan yang dilakukan oleh guru setelah satu pokok bahasan selesai dipelajari oleh siswa. Evaluasi formatif terutama dimaksudkan untuk memberikan umpan balik kepada guru mengenai keberhasilan program mengajarnya. Dalam hal ini, keberhasilan siswa merupakan petunjuk utama keberhasilan program mengajar yang diselenggarakan oleh guru pemegang bidang studi yang bersangkutan, dan jenis evaluasi ini dikenal sebagai ulangan harian.

Evaluasi sumatif atau dikenal dengan tes sumatif adalah tes yang diselenggarakan oleh guru setelah satu jangka waktu tertentu. Tes sumatif ini dalam pelaksanaannya sering disebut dengan ulangan umum yang biasanya diselenggarakan secara serentak untuk seluruh sekolah. Butir-butir soal untuk tes sumatif, jumlah dan kualitasnya harus lebih dibandingkan dengan butir-butir dalam tes formatif. Perlu diperhatikan bahwa tes sumatif bukan hanya sekedar gabungan dan soal-soal tes formatif atau memilih beberapa butir soal formatif. Beberapa butir soal harus mengukur kemampuan siswa dalam kaitannya dengan pengertianpengertian yang terkandung memuat pendidikan karakter.

Penilaian hasil belajar bagi peserta didik, sistem evaluasinya, penilaian harian terdiri dari Postes dan pretes, dengan jenis tes tulis dan tugas. Bentuk instrumen: tes subjektif, tes objektif, dan tugas individual yang mengandung nilai-nilai karakter. Dengan bidang penilaian kerjasama kelompok, mengajukan pertanyaan, menjawab pertanyaan dengan benar. Dengan kriteria konversi nilai 90 sangat baik, konversi nilai 80 baik, 70 cukup, dan 60 kurang. Penilaian hasil semester dilakukan dalam bentuk buku raport anak murid dengan Kriteria Ketuntasan Minimal untuk pelajaran pendidikan agama 85 dengan melakukan evaluasi dengan memberikan pertanyaan seputar indikator. Nilai yang ditanamkan: disiplin, kerja keras, kreatif, rasa ingin tahu, cinta tanah air, menghargai prestasi, bersahabat, cinta damai, gemar membaca, tanggung jawab, bidang penilaian, kerjasama kelompok, mengajukan pertanyaan, menjawab pertanyaan dengan benar, partisipasi yang mengandung nilainilai karakter. Hasil dari proses pembelajaran berkaitan dengan penguasaan siswa terhadap materi pembelajaran yang memuat tentang nilai karakter yang dapat dilihat saat atau pun setelah pembelajaraan melalui evaluasi.

\section{Pendukung dan Penghambat}

Implementasipendidikankarakterdidukung oleh managemen madrasah berbasis pesantren dan semua peserta didik diasramakan yang berasal dari 10 kabupaten di provinsi Sulawesi Tengah, pendidikan karakter dapat diimplementasikan secara maksimal karena semua siswi diasramakan sehingga lebih mudah dibimbing dan diarahkan ke nilai-nilai karakter yang ditargetkan, metode dan pendekatan yang digunakan dipadukan dengan metode berbasis pesantren. Sarana dan prasarana yang mendukung diantaranya sekolah dan Asrama gratis.

Faktor penghambat di dalam mengimplementasikan pendidikan karakter diantaranya guru mengajar tidak sesuai dengan kompetensi professional, sarana dan prasarana masih kurang diantaranya media pembelajaran dan peralatannya laptop, komputer, proyektor, pihak madrasah dan pihak asrama belum sinergi dalam menentukan kegiatan ekstrakulikuler yang berubungan dengan pendidikan karakter, Kegiatan ekstrakulikuler pada sore dan malam hari belum memakai sistem klasikal, semua siswi mulai dari tingkat Madrasah Ibtidaiyah, Madrasah Tsanawiyah, Madrasah Aliyah masih digabung ketika proses pembelajaran dilaksanakan sehingga tidak ada klasifikasi mata pelajaran pada masing-masing tingkatan. Metode yang digunakan pada kegiatan pengembangan diri dan ekstrakulikuler pada sore dan malam hari di asrama masih menggunakan metode ceramah, karena siswi digabung mulai dari MI sampai MA.

\section{PENUTUP}

Implementasi pendidikan karakter di MA Puteri Aisyiah telah dilaksanakan pada mata pelajaran terlihat pada pelajaran Aqidah Akhlaq, integratif melalui kultur madrasah pembiasaan, 
keteladanan, pengembangan diri dan pada karakteristik madrasah melalui pencitraan ketika memasuki pintu gerbang sekolah dan hampir setiap dinding sekolah tertulis pesan dan kesan pendidikan karakter yang termuat dalam 18 butir diantaranya $8 \mathrm{~K}$ (ketakwaan, keindahan, kebersihan, kesehatan, keamanan, ketertiban, kekeluargaan, dan keindahan). Kemudian pada setiap pintu masuk tertuliskan pesan dengan kata "saya malu jika datang terlambat dan saya malu jika cepat pulang". Dan pada waktu shalat tiba seluruh kegiatan dihentikan untuk menjalankan.

Pendidikan karakter terlihat pada Rencana Pelaksanaan Pembelajaran dan pada proses pembelajaran, terlihat pada kegiatan langkahlangkah pembelajaran kegiatan pendahuluan, inti, dan penutup. Namun, pada implementasinya guru masih mengalami kendala dalam penanaman nilainilai karakter pada setiap mata pelajaran variatif. Setiap mata pelajaran memfokuskan pada penanaman nilai-nilai utama tertentu yang paling dekat dengan karakteristik mata pelajaran yang bersangkutan.

Faktor pendukung implementasi pendidikan karakter di MA putri Aisiyah Palu diantaranya managemen madrasah yang berbasis pesantren, semua peserta didik diasramakan yang berasal dari 10 kabupaten di provinsi sulawesi tengah. Pendidikan karakter dapat diimplementasikan secara maksimal karena semua siswi diasramakan sehingga lebih mudah dibimbing dan diarahkan ke nilai-nilai karakter yang ditargetkan. Metode dan pendekatan yang digunakan dalam pembelajaran selain menggunakan metode pada umumnya juga menggunakan metode yang dipadukan dengan metode berbasis pesantren.

Faktor penghambat masih terdapat guru mengajar tidak sesuai dengan kompetensi profesional, pihak madrasah dan pihak asrama belum sinergi dalam menentukan kegiatan ekstrakulikuler. Kegiatan ekstrakulikuler pada sore dan malam hari belum memakai sistem klasikal, semua siswi mulai dari tingkat Madrasah Ibtidaiyah, Madrasah Tsanawiyah, Madrasah Aliyah masih digabung ketika proses pembelajaran dilaksanakan sehingga tidak ada klasifikasi mata pelajaran pada masing-masing tingkatan. Metode yang digunakan pada kegiatan pengembangan diri dan ekstrakulikuler pada sore dan malam hari di asrama masih menggunakan metode ceramah. Pembinaan dan pelatihan secara langusng kepada guru-guru madrasah oleh berbagai pihak terkait belum menyentuh terutama dalam pembuatan RPP dan silabus.

\section{UCAPAN TERIMA KASIH}

Terima kasih yang tak terhingga penulis haturkan kepada Kepala Balai Penelitian dan Pengembangan Agama Makassar yang telah memberikan motivasi dan amanah untuk terus berkarya dengan melakukan penelitian di Kota Palu, kepala Madrasah Aliyah Puteri Aisyiah Palu Ibu Nuraidah yang telah memberikan izin melakukan penelitian, dan semua pihak yang terkait dalam pengumpulan data. Ucapan terima kasih penulis haturkan kepada Mitra Bestari, tim redaksi ALQalam atas di terbitkannya tulisan ini.

\section{DAFTAR PUSTAKA}

Abdullah, Abdurrahman Saleh. 2005. Teori-teori Pendidikan Berdasarkan Al-Qur'an, (terj.) Dari Educational Theory a Quranic Outlook. Cet. III. Jakarta: Rineka Cipta.

Bogdan, Robert C. \& Sari Knopp Biklen. 1982. Qualitative Research For Education. Boston: Allyn and Bacon Inc.

Fatchurochman, Nanang. 2012. Madrasah Sekolah Islam Terpadu, Plus dan Unggulan. Cet. II. Depok: Lentera Hati Pustaka.

Gede Raka, 2012. Pendidikan Moral Dan Spiritual Dalam membangun Karakter Bangsa (Analisis Kitab Nashoihul 'Ibad karya Syaikh Nawawi 1-Bantani), Puslitbang pendidikan Agama Dan Keagamaan Badan Litbang Dan Diklat Kementerian Agama RI. Jakarta.

Gunawan, Heri. 2012, Pendidikan Karakter konsep dan Implementasi, Bandung: Alfabeta.

Hasballah. 1999, Dasar-Dasar Ilmu Pendidikan. Jakarta: Raja Grafindo Persada.

Kesuma, Dharma Dkk. 2012. Pendidikan Karakter Kajian Teori Dan Praktek di Sekolah, Cetakan III. Bandung: PT. Remaja Rosdakarya.

Muslich, Masnur. 2011. Pendidikan Karakter Menjawab Tantangan Krisis Multidimensional. Jakarta: Bumi Aksara.

Nury, Firdausi. 2012. Pendidikan Moral Dan 
Spiritual Dalam Membangun Karakter Bangsa (Analisis Kitab Nashoihul 'Ibad karya Syaikh Nawawi 1-Bantani), Puslitbang pendidikan Agama Dan Keagamaan Badan Litbang Dan Diklat Kementerian Agama RI. Jakarta.

Prawiroatmojo, Dendasurono, dkk. (ed). 1987. Pendidikan Kependudukan Dan Lingkungan Hidup Sekolah Menengah Atas, Jakarta: P \& K Dikdasmen Depdikbud.

Sahlan, Asmau, dan Angga Teguh Prasetyo. 2012. Desain Pembelajaran Berbasis Pendidikan Karakter. Yogyakarta: Ar.Ruzz Media.
Sugiyono. 2005. Memahami Penelitian Kualitatif. Bandung: Alfabeta

Sukmadinata, dkk. 2008. Pengendalian Mutu Pendidikan Sekolah Menengah. (Konsep, Prinsip dan Instrumen). Bandung: Refika Aditama

Sungkowo. 2009. Panduan Pencegahan Dan Penanggulangan Penyimpangan Perilaku Siswa Sekolah Menengah Atas, Departemen Pendidikan Nasional, Direktorat Jenderal Manajemen Pendidikan dasar Dan Menengah Direktorat Pembinaan Sekolah Menengah Atas. Jakarta. 